Stream: Inspiring Critical Thought

2017, Vol 9(1), 14-19

(C) The Author(s), 2017

http://journals.sfu.ca/stream

\title{
Long Lost Lore of a 'Land' Called Home
}

\author{
Gopa Biswas Caesar \\ School of Communication \\ Simon Fraser University
}

Each of those people carries, and passes down, a story of unimaginable pain, hate, horror, but yearning too. That wound, those torn but still un-severed muscles, that blocked and those splintered bones still lock us together in a close embrace of hatred, terrifying familiarity, but also love.

- Arundhati Roy (2008)

I grew up in a household that crossed boundaries. And as a result, I faced relentless questions from my classmates, their parents, my neighbors, local shopkeepers, even pedestrians. Asking uncomfortable questions to minority people like "why don't you eat beef?" or "why don't your men undergo circumcisions?" or "why do you give sambar to your lentil soup?" is normal in Bangladesh, where I live. I was taught to overlook these questions - to know them as rhetorical queries, to which there can be no sane reply. What justified the casual insults hurled at me as a representative of a minority?

My mother was from Kolkata (Calcutta), in the Indian province of West Bengal. She was born decades after India's Partition, so she was thought of as Indian rather than Bengali. She had a heavy Kolkatan accent and served less spicy foods. Her meals always included a compulsory sweet dessert. People, including my paternal family members, started calling her Ghoti which is a demeaning (if not derogatory) term for people from West Bengal. Historically Ghoti-culture is babu-culture or gentleman's culture (Gangopadhyay, 1989, p. 317). So it is interesting to note that my compatriots started calling themselves Bangals which is a demeaning term used to refer to people from East Bengal. They took pride in holding an identity utterly different from the Ghoties, even if it meant adopting the term Bangal to describe themselves.

It was both awe-provoking and awakening to know as a six-year-old in the first week of school that I spoke a different language. It's not that I didn't realize that I spoke differently. I picked up my Mother's accent at a very early age. But my parents both spoke the same language, and I spoke it as well, so what was the issue? I soon learned that I had a "fake" accent which was pretentious and too elegant. Didn't I realize that I was speaking another language which was not supposed to be mine? I wonder why these people were so desperate to pin down the features that distinguished them from others. Even a half a century ago my mother's accent would not have mattered as long as she could speak Bengali. Nobody would have cared if her desserts were sweeter. But in post-partition Bengal, people went to great efforts to mark themselves as different. 


\section{The Creation of Difference}

In the final days of the British Raj, the Indian subcontinent was inhabited by contested ethnopolitical blocks. While Mahatma Gandhi had always dreamt of an undivided Indian land with a heterogeneous integrated culture, Muhammad Ali Jinnah advocated the notorious Two Nation Theory which would slice off a new nation with its own language, ethnic origin and culture. Rejecting Mahatma Gandhi's pleas, Jawaharlal Nehru and Jinnah chose to be the fathers of the 'Two Nations.' They created a nation-state for Muslims, cut it into two pieces that separated from each other by 1600 kilometers of Indian territory. The northeast piece became East Pakistan and northwest piece became West Pakistan. On August 15, 1947 "...at the stroke of the midnight hour, when the world sleeps..." the two countries were renamed based on the dominant religion of each land. Hindustan meant land of Hindus and Pakistan meant land of purity (as Islam is considered the purest religion of all by Muslims). Thus, overnight Hindu Bengali people became Indians, and Muslim Bengali people became Pakistanis. Riots broke out immediately. Muslims took Jinnah's words about partition literally and started looting Hindu and Sikh lands and properties. The reverse happened to Muslims living in the 'land of Hindus' (Gangopadhyay, 1989, p. 43). Wearing sindoor, a hijab or a turban could result in bullying or worse. Trauma crawled in everyone.

Within a few decades, the Muslim's pure paak (land) had become tainted. East Pakistan was always looked down upon by West Pakistan since the west had the capital city of Karachi, as well as the central banking system. Also, Jinnah announced Urdu would become the state-language of Pakistan even though $56 \%$ of the country's population spoke Bengali. Bengalis were much more passionate about their language and culture than Jinnah estimated. They proved they could die to save the essence of the Bengali people. After protracted military suppression of Bengali people by the central government, East Pakistan declared war on West Pakistan. During the war, refugees flooded out of East Pakistan into the bordering Indian province of West Bengal, choking the city of Kolkata. War-stricken East Pakistan and West Bengal both suffered enormously during this period. This was partly because West Bengal had a communist government at the time, which was out of favor with the Indian National Congress Party. When "East Bengal" called for support during the 1971, West Bengal sacrificed enormously to help its 'severed' half achieve their journey towards independence.

After a nine-month war of liberation, assisted by India, Bangladesh won its independence in 1971. The Bengali community was overjoyed to see secularism and democracy restored. India was overjoyed because refugees could now return to their homeland. But Bangladesh did not have an easy birth, and many questions lingered. Couldn't East Bengal (Bangladesh) and West Bengla (of India) reunite and be the "Bengal of Gold"1 again? In the decades since, Bangladesh has lived with both the repressed traumas of the Bengali cleavage, and a sense of nostalgia around re-unification.

I wish to celebrate my own sovereignty much more than the re-unification of the two Bengals. Therefore, I ought to move on from the Partition like most others of my generation do. And yet, I care about the Partition because while there is no difference in the language that is spoken in the 
two Bengalis, the lack of understanding is deep. As a minority person living in Bangladesh, this affects me personally. I care more and more about the Partition as time goes by because very soon a generation of mourners will be gone. Who will cultivate nostalgia for a reunited Bengali community then? And if that melancholia is gone, how will we find our way towards a more understanding culture?

\section{Rendezvous with Ghatak}

I visited my maternal grandparents' home in Kolkata for the first time when I was twenty-two years old. Growing up in Bangladesh, I was brought up on stereotyped stories about the people of West Bengal. But I found West Bengali's to be no different from my grandparents. I met their neighbours who left East Bengal during the Partition. They spoke fondly of a lost land and shed tears over the silly cows they had to leave behind with their Muslim neighbours. They missed Eid as well as inviting the old neighbors at pujas. My encounters with West Bengalis were mesmerizing. I hadn't realized my country had so many hidden treasures to be fond of.

I also met a Muslim friend at university who had an accent similar to my mother's. I came to know that his grandparents also fled Kolkata during the Partition. I began to understand that Bangladesh suffers from a collective trauma, and I sought to make sense of this awakening realization. Ritwik Ghatak's works became the primary window through which I developed this understanding.

I first became intimate with Ghatak's works on the Partition while I was volunteering at a film festival. In his own words: "Being a Bengali from East Bengal, I have seen the untold miseries inflicted on my people in the name of independence-which is a fake and a sham. I have reacted violently towards this and have tried to portray different aspects of this [in my films]" (Ghatak, 2000, p. 18). I was awed by the pain this filmmaker's shots portrayed. The Partition, literally, destroyed this maestro. He was never at peace as he knew things had gone terribly wrong.

I studied Ghatak extensively to learn more about him. There are hundreds of papers written on Ghatak and almost all of them talk about how far ahead of his contemporaries he was. But they also noted how neglected his works have been (Galt and Schoonover, 2010, p. 23). The Bengali film community was reckless about preserving his film-reels, and most of them are in very bad shape. This has not stopped detailed analysis of his technical brilliance (Chatterjee, 2003). His powerful use Brechtian methods and melodrama influenced me immensely during my years at film school. He used Brechtian methods to remind the audience that they are watching a film, and not 'real life,' such that they would be more thoughtful and engaged. Brechtian methods include dream sequences, cross cutting, direct addressed to the audience to break the fourth wall, flash-backs (as they interrupt the continuity of the narrative), tableau effects created by freeze frames, jump cuts connoting spatial dislocation, non-linear story-telling, revealing film techniques like camera, projector, shooting, clapsticks etc., conflicting shots like a long-shot followed by a big close-up, using inserts, gestus, self-reflexivity, creating jolts, contrapuntal sound, unusual camera angles, use of negatives, voice over, mise-en-scene etc. (Rajadhyaksha, 1982, p. 29). Ghatak was also the one who introduced mel- 
odrama in a proper sense in 'our' (i.e. Bengali) films. Ghatak was an out and out theatre person. He came to film only because film could reach many more people than theatre. His trauma was such that it required melodrama to bring sense to it.

The films Meghe Dhaka Tara (1960), Komal Gandhar (1960), and Subarnarekha (1961) form Ghatak's Partition trilogy. India's Partition happened almost 70 year ago. In the first 15 years after partition, there were four major films on the topic, but then the genre dried up. More recent films trivialized the Partition, making it the butt of jokes. How can we read the representations as well as the absences of partition in prominent Bengali cinematic works?

Despite the detailed analysis of Ghatak's genre, very few works have tried to read his trauma, and how he planted the seeds of melancholia in each of the eight films that he made. There is almost no work that talks about the post-colonial and the Brechtian role of melodrama in his films, and few read his films as Third Cinema. ${ }^{2}$ In addition, whenever we talk about partition films we always go all the way back to Ghatak's works from the early 1960's. Critics never seem to notice how the trauma of the Partition is being trivialized in the films that follow on Ghatak's partition trilogy. This is troubling because contemporary audiences are quite divided (and divisive) in their reaction to border-crossing film. Cinema from West Bengals often positions Bangal's as the buffoons who engage in stupid acts. Meanwhile, in Bangladesh, audiences openly despise a Kolkatan accent. As a result, there has been little analysis of how Ghatak's films create the possibility for rethinking culture in Bangladesh, or how the passing of his genre is a lost opportunity for our nation.

Ghatak's ability to provoke melancholy and nostalgia for our Bengali past is literally disintegrating on the reel, while contemporary theatre enforces the very partition that Ghatak saw as "a fake and a sham." As the French historian Ernest Renan put it in 1882 "nations are based as much on what the people jointly forget, as what they remember." But as another well-known historian of the Indian Partition, Mushirul Hasan, points out, history cannot capture the complexity of such an experience. For that, one has to look to creative writing (Hasan, 2006). The Caribbean poets Edward Kamau Brathwaite and Derek Walcott found refuge in this approach. Salman Rushdie, Sunil Gangopadhyay and Humayun Ahmed advocated it. We can study the history of Bengal's Partition through the poetry of Ghatak's cinematic works, and also discover pathways to our future there.

\section{Making Sense of Ghatak and Myself}

The Bangladesh-India border (i.e. the Radcliffe border) is the most porous border in the world (Chatterjee et al. and Ghose). The exodus that began during the time of Partition continues to this day as minority groups respond to violent attacks and are forced to desert their inherited lands. Dr. Abul Barkat, a renowned professor of University of Dhaka estimates that "[n]o Hindus will be left after thirty years" in his 2016 book Political Economy of Unpeopling of Indigenous People: The case of Bangladesh (Hasan, 2016). I experience these pressures myself. In my role as an instructor at the Bangladesh University of Engineering and Technology (BUET) I have been asked by a prominent faculty member why I am still in Bangladesh given that, by religion, I belong to India. Another 'illus- 
trious' figure talked about red ants and black ants. He claimed to believe that black ants are Muslims and red ants are Hindus. (Since married Hindu women wear red vermillion, red is often identified with Hinduism by Islamic fundamentalists). He went on to explain that when black ants bite, it does not burn. But, when the red ants bite, it burns because Hindus are poisonous and evil. I fumed and disagreed vehemently, but then I was signaled not to utter a word by some senior professors. I dare not wish to see the two Bengals unite again the way my grandparents did; it is not only impossible but also impractical. I fear that the religious violence that is already happening in Bangladesh would explode if this were attempted. It is not an unreasonable fear. In 1992, a large group of Hindu devotees attempted to demolish a mosque in the city of Ayodhya, in Faizabad, India because a rumour circulated that it had been a temple in the $16^{\text {th }}$ century. I do not understand why the group would want to demolish a mosque with 400 years of history. But it is even harder to understand why Hindu people on the Bangladeshi side of the border would face violence because of this: when news of the incident spread to Bangladesh, the Muslim majority started beating up Hindu men, and fundamentalist 'youngsters' raped Hindu women to violate the honour of the 'Hindus.' A Muslim doctor named Taslima Nasreen who treated the floods of Hindus injured in the resulting violence published a book about the episode called Lajja (i.e. Shame). Her book was banned and she was eventually exiled!

Moreover, both the sides will feel they are compensating the 'other' as we have already become two. The collective memory of half a century is already providing us with a certain sense of comfort in being different from each other. Unlearning that is something next to impossible.

But if reunification is impractical, then how can minority groups in Bangladesh achieve some measure of acceptance? There is a culture of fear, of hushed consciousness in my country. If I were writing this paper in Bangladesh, I would not write so explicitly. My mind would auto-censor. I would write about something else. I desperately want to walk out of this culture of censoring/filtering each word I have to utter. I want to move past a discussion of the technical aspects of film, and to engage in something more than the merely secular and liberal. I want to recover the nostalgia and melancholy of Ghatak because this can open up a conversation about who we are as a country, and how we want to be.

My challenge, therefore, is to figure out how to read Ghatak's works in a way that does justice to my own positionality as a product of the trauma of partition. His works can reveal new insights about our collective trauma, and the power of our nostalgia and melancholy, while also providing me with a way to know myself better. They allow me to study the trauma I inherited from a time when 'we' (i.e. the Hindu people and other minorities) faced threats of ethnic cleansing. They allow me to take up many of the things I am passionate about: my family and our identity in a land which we claim to be ours but which does not claim us back. I feel I have inherited not only the trauma of an older generation, but also a sense of duty towards the people who had no voice against the claim of independence. I stand on a stronger platform therefore I must speak or risk doing an injustice to millions who lost their home and honour to the Partition. As a communicator, I want to engage with nostalgia for another time and write for a future when I can walk proud as a Bengali person. 


\section{Notes}

1. "Bengal of Gold" is taken from the Bengali national anthem written by Rabindranath Tagore and popularized by the father of the nation, Bangabandhu Sheikh Mujibur Rahman.

2. In "Towards the Third Cinema” (1969) Fernando Solanas and Oc ptavio Getino identify a category of film that addresses social anomalies and fights the establishment through the application of specific techniques such as Brechtian methods (Guneratne, 2003).

\section{References}

Bhattacharya, S., \& Dasgupta, S. (Eds). (2003). Ritwik Ghatak: Face to face. Calcutta, IN: Cine Central. Daiya, K. (2008). Violent belongings: Partition, gender and national culture in postcolonial India. Philadelphia, PA: Temple University Press.

Chatterjee, P. (2003). The relentless tragedy of Ritwik. Retrieved from http://old.himalmag.com/

Chatterjee, P. et al. (Producer), \& Ghose, G. (Director). (2016). Shankhachil [Motion Picture]. Bangladesh \& India: Ashirbad Cholochitro, Impress Telefilm Ltd, NIdeas Creations \& Productions.

Galt, R., \& Schoonover, K. (2010). Introduction. In R. Galt, \& K. Schoonover (Eds.), Global art cinema: New theories and ishtories (pp. 3-30). New York, NY: Oxford University Press.

Gangopadhyay, S. (1989). Purba-Pashchim. Culcutta, IN: Ananda Publishers.

Ghatak, R. (1987). Cinema and I. Culcutta, IN: Ritwik Memorial Trust.

Ghatak, R. (2000). Rows and rows of fences: Ritwik Ghatak on cinema. Culcutta, IN: Seagull Books Pvt. Ltd.

Raychowdhuri, S. (2000). Partition trauma, the oedipal pupture, dreaming: The cinematic will of Ritwik Kumar Ghatak, Calcutta, IN: Papyrus.

Hasan, K. (2016, November 21). No Hindu will be left after 30 years. Dhaka Tribune. Retrieved from http://www.dhakatribune.com

Rajadhyaksha, A. (1982). Ritwik Ghatak: A return to the epic. Mumbai, IN: Screen Unit.

Roy, A. G., \& Bhatia, N. (Eds). (2008). Partitioned lives: Narratives of home, displacement, and resettlement. Delhi, IN: Pearson Education.

Basu Roy, I. (2005). Deshbhag O Ritwik Ghatak-er Cinema (partition and the cinema of Ritwik Ghatak). Nillohit, March 2005: 177-184.

Sarker, B. (2009). Mourning the nation: Indian cinema in the wake of partition. Durham, NC: Duke University Press. 